\title{
Drawing Red Lines with No (Significant) Bites: Why an Individual Test Is Not Appropriate in the $L M$ Case
}

\author{
Agnieszka Frąckowiak-Adamska
}

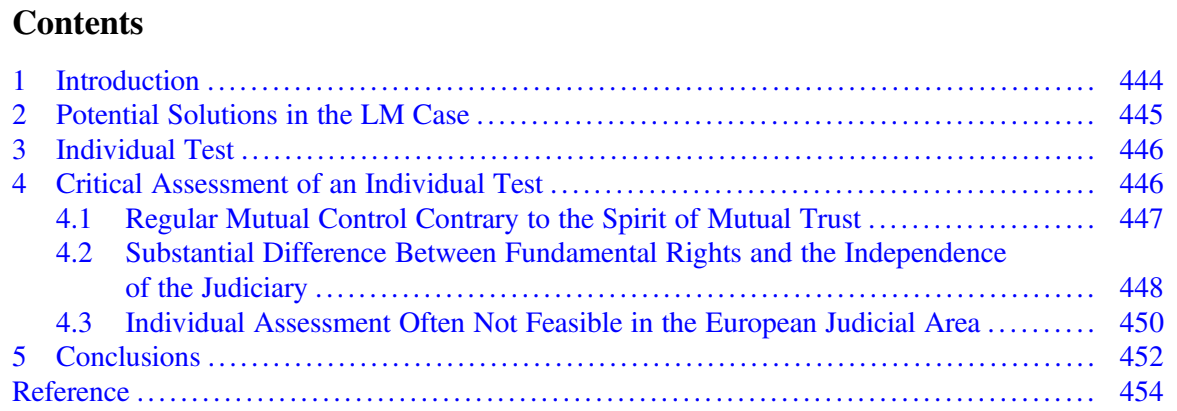

\begin{abstract}
This contribution argues that an obligation for an executing court to conduct an individual assessment in case of systemic deficiencies of the judiciary in other Member States is not an adequate tool for ensuring the respect for the rule of law. Infringements of the independence of the judiciary require other legal mechanisms of protection than fundamental rights. Moreover, individual test is often not feasible in the European judicial area as some other acts providing for recognition of judgments in the EU do not contain the mechanisms of refusal of recognition or execution. A breach of the obligation to ensure independence of the courts should logically result in suspending the participation of a given Member State in the EU policy area at stake.
\end{abstract}

This Chapter draws on 'Drawing Red Lines With No (Significant) Bites-Why An Individual Test Is Not Appropriate in the LM Case', Verfassungsblog (30 July 2020) and 'Mutual trust and independence of the judiciary after the CJEU judgment in LM - new era or business as usual?', EU Law Analysis (15 August 2018).

\footnotetext{
A. Frąckowiak-Adamska $(\bowtie)$

University of Wrocław, Wrocław, Poland

e-mail: agnieszka.frackowiak-adamska@uwr.edu.pl
} 


\section{Introduction}

The judgment in the $L M^{1}$ case was much expected as the first opportunity for the Court of Justice of the EU to assess the consequences of the systemic changes restricting judicial independence in Poland. The sequence of laws adopted in $2015-2018^{2}$ in this State has been assessed commonly by various external and internal institutions as '[enabling] the legislative and executive powers to interfere in a severe and extensive manner in the administration of justice and thereby [posing] a grave threat to the judicial independence as a key element of the rule of law'. ${ }^{3}$ These reforms are problematic for the EU as the national courts shall ensure an 'effective legal protection in the fields covered by Union law'. ${ }^{4}$ But they also pose a problem for other Member States because of mechanisms of judicial cooperation established by the EU in last 19 years as a part of area of freedom, security and justice.

The open questions are whether these reforms should have consequences for the position of Poland in the EU and if yes, who should draw them and how. To protect the rule of law in Europe, the European Commission submitted for the first time in its history a reasoned proposal activating the Article 7 TEU mechanism. ${ }^{5}$ The proceedings against Poland based on Article 258 TFEU are also ongoing. ${ }^{6}$ The $L M$ case hinges on the horizontal aspect of the changes - verifying the state of the rule of law

\footnotetext{
${ }^{1}$ CJEU, Case C-216/18 PPU, Minister for Justice and Equality (LM), ECLI:EU:C:2018:586.

${ }^{2}$ Described in Report of the Stefan Batory Foundation Legal Expert Group on the impact of the judiciary reform in Poland in 2015-2018.

${ }^{3}$ CDL-AD(2017)031-e Poland-Opinion of the European Commission For Democracy Through Law on the Draft Act amending the Act on the National Council of the Judiciary; on the Draft Act amending the Act on the Supreme Court, proposed by the President of Poland, and on the Act on the Organisation of Ordinary Courts, adopted by the Commission at its 113th Plenary Session (Venice, 8-9 December 2017). Similar opinions were expressed i.a. by the European Commission, the Executive Board of the European Network of Councils for the Judiciary (ENCJ), www.encj.eu/ articles/96, Polish Supreme Court, Polish faculties of law, independent nongovernmental organisations.
}

${ }^{4}$ Article 19 (1) TEU. See also CJEU, Opinion 1/09, ECLI:EU:C:2011:123, para. 68: 'it is for the national courts and tribunals and for the Court of Justice to ensure the full application of European Union law in all Member States and to ensure judicial protection of an individual's rights under that law' and para. 69: 'The national court, in collaboration with the Court of Justice, fulfils a duty entrusted to them both of ensuring that in the interpretation and application of the Treaties the law is observed'.

${ }^{5}$ European Commission, Reasoned proposal of 20 December 2018 in accordance with Article 7 (1) of the Treaty on European Union regarding the rule of law in Poland, $\operatorname{COM(2017)~} 835$ final.

${ }^{6}$ At the time of deciding the $L M$ case, the case C-192/18 on the law on the ordinary courts organisation was already pending before the CJEU (action brought on 15 March 2018). And infringement procedure regarding the Polish law on the Supreme Court was launched by the Commission only on 2 July 2018. At the time of deciding the $L M$ case it was thus at the pre-trial stage and it was not evident at all that the Commission will decide to bring an action to the court. Finally, the action was brought on 2 October 2018 and registered as Case C-619/18 Commission v. Poland. 
by courts of the other Member States. In the case, in which the European Arrest Warrant (EAW) was issued by a Polish judicial authority against a person prosecuted for a drug-related crime, the defendant argued before an Irish court that due to the reforms of the Polish judiciary there is a risk of denial of justice if he is transferred to Poland.

Has the Court of Justice (hereinafter CJEU), in deciding the $L M$ case, drawn red lines for Member States in the context of the rule of law? It could be admitted that it set 'a limit beyond which someone's [Member State's] behavior is no longer acceptable ${ }^{77}$ but it could also be argued that it did not establish adequate consequences of crossing it. The Luxemburg court focused on the protection of individuals, leaving the issue of systemic consequences to the Council acting on the basis of Article 7 TEU. This contribution argues that an individual test required by the $L M$ judgment is not an adequate tool for ensuring the respect for the rule of law.

\section{Potential Solutions in the LM Case}

The Irish question was based on the CJEU's case law relating to the protection of fundamental rights in the context of mutual recognition of judgments in criminal matters $\left(\right.$ Aranyosi $\left.^{8}\right)$. According to the latter case, if a court taking the decision on extradition on the basis of an EAW possesses evidence of systemic or generalised deficiencies in the protection of fundamental right in the issuing Member State, it should postpone the execution and assess whether the individual concerned will be exposed to a real risk of inhuman or degrading treatment because of the conditions during detention. The CJEU in the $L M$ case had three main options: (1) to refrain from assessing the impact of the restriction of judicial independence on the EAW mechanism (following Poland's argument that it is possible only by the Council on the basis of Article 7 TEU), (2) to follow the Aranyosi pattern or (3) to introduce a new mechanism if the independence of the courts is doubtful in the Member State issuing the judicial decision (building on its recent decision in the case Associação Sindical dos Juízes Portugueses, ${ }^{9}$ in which it stated that Member States are obliged to ensure independence of the courts).

The $L M$ judgment treated an issue of judicial independence as a part of a right to a fair trial protected by Article 47 of the Charter. It allowed the CJEU to follow the Aranyosi path and base its answer on a similar pattern: if the court executing an EAW from another Member State possesses the information that there is a real risk of a breach of the fundamental right to fair trial due to systemic or generalised

\footnotetext{
${ }^{7}$ See Cambridge Dictionary, see dictionary.cambridge.org/pl/dictionary/english/red-line.

${ }^{8}$ CJEU, Joined Cases C-404/15 and C-659/15 PPU, Aranyosi and Căldăraru, ECLI:EU: C:2016:198.

${ }^{9}$ CJEU, Case C-64/16, Associação Sindical dos Juízes Portugueses, ECLI:EU:C:2018:117, para. 37.
} 
deficiencies concerning the independence of the issuing Member State's judiciary, it shall assess whether the person incurs such a risk if he is surrendered to that State (individual or specific assessment). ${ }^{10}$ The CJEU indicated that the suspending of the mechanism of recognition is possible only if the decision is taken on the basis of Article 7(2) TEU. ${ }^{11}$ Until this moment even if a Member State is the subject of a reasoned proposal as referred to in Article 7(1) TEU, the 'executing judicial authority must refrain from giving effect to the European arrest warrant' only if there are substantial grounds for believing that that person will run a real risk of breach of the fundamental right to a fair trial. ${ }^{12}$

\section{Individual Test}

An executing judicial authority conducting an individual test should verify firstly 'to what extent the systemic or generalised deficiencies are liable to have an impact at the level of that State's courts with jurisdiction over the proceedings to which the requested person will be subject'. Then it should verify whether there is a real risk of breach of his fundamental right to an independent tribunal having regard to his personal situation, the nature of the offence for which he is being prosecuted and the factual context that forms the basis of the European arrest warrant. The sources of knowledge are: (1) specific concerns expressed by the individual concerned and any information provided by him, (2) any supplementary information obtained from the issuing judicial authority in the answer to the (mandatory) request made by the executing authority, (3) (optional) assistance from the central authority or one of the central authorities of the issuing Member State. ${ }^{13}$ If the information obtained in such a way by the executing judicial authority 'does not lead the latter to discount the existence of a real risk [for the individual concerned] (...) the executing judicial authority must refrain from giving effect to the European arrest warrant' ${ }^{14}$

\section{Critical Assessment of an Individual Test}

It can be argued that an obligation for an executing court to conduct an individual assessment in case of systemic deficiencies of the judiciary in other Member States reverses the logic of the mutual trust developed by the CJEU (Sect. 4.1). Furthermore it is not the proper test to protect the rule of law due to two reasons. Firstly

\footnotetext{
${ }^{10} \mathrm{CJEU}$, LM, supra note 1, para. 79.

${ }^{11}$ Id., paras. 71-73.

${ }^{12}$ Id., paras. 78 and 59.

${ }^{13}$ Id., paras. 75-78.

${ }^{14}$ Id., para. 78 .
} 
(Sect. 4.2), there is a substantial difference between fundamental rights and the independence of the judiciary. Infringements of the latter require other legal mechanisms of protection deterring a Member State from restricting judicial independence. Secondly (Sect. 4.3), the individual test is often not feasible in the European judicial area as some other acts providing for recognition of judgments in the EU do not contain the mechanisms of refusal of recognition or execution. A broader perspective should be taken as Polish institutional changes affecting judicial independence may influence all twenty-six EU acts providing for mutual recognition of judgments.

\subsection{Regular Mutual Control Contrary to the Spirit of Mutual Trust}

According to the CJEU the principle of mutual trust has a fundamental importance and 'requires (...) each of those States, save in exceptional circumstances, to consider all the other Member States to be complying with EU law and particularly with the fundamental rights recognised by EU law'. ${ }^{15}$ But according to para. 69 of the $L M$ judgment, when the issuing Member State has been the subject of a (well) reasoned proposal adopted by the Commission pursuant to Article 7(1) TEU, ${ }^{16}$ the executing court is obliged to pursue a regular control. The fact of starting the Article 7 TEU procedure thus rebuts the presumption of mutual trust as the individual assessment is required in every case in which the person subject to EAW pleads it. ${ }^{17}$

Perhaps the CJEU treated this obligation as a tool of pressure on the Member State restricting the independence of the judiciary contrary to the recommendations of the Commission-applied until the decision on the basis of Article 7(2) TEU is taken. But a regular control of judicial decisions from other Member States reverses the logic of mutual trust and can impair it in the long term (as taking a decision on the basis of Article 7(2) TEU which requires unanimity is not very probable). From the perspective of mutual trust a better solution would be if a decision of a Member State to restrict the independence of the courts (assessed as systemic deficiencies) implied a temporary suspension of its participation in all legal acts based on mutual trust in the administration of justice.

\footnotetext{
${ }^{15} \mathrm{CJEU}$, Opinion 2/13 Accession of the EU to the European Convention for the Protection of Human Rights and Fundamental Freedoms, ECLI:EU:C:2014:2454, para. 191.

${ }^{16}$ Based on actions impairing the independence of national courts.

${ }^{17} \mathrm{CJEU}$, LM, supra note 1, paras. 60 and 68-69.
} 


\subsection{Substantial Difference Between Fundamental Rights and the Independence of the Judiciary}

The answer in the $L M$ judgment was based on the interpretation of Article 1 (3) of the EAW framework decision which states that this act shall not modify 'the obligation to respect fundamental rights and fundamental legal principles as enshrined in Article 6 [TEU]'. ${ }^{18}$ But there is a substantial difference between fundamental rights and the independence of the judiciary. Both values are certainly interconnected: the independence of the judiciary is in particular a part of the right to effective judicial protection. But it is not limited to this aspect. Fundamental rights are entitlements of individuals and it is therefore possible to verify whether they are ensured in individual situations. The independence of the judiciary is important in an individual case, but it also remains a key element of the State's system, indispensable to ensuring the right balance between public and private interests. In the EU, it also guarantees securing effective legal protection in the fields covered by Union law. It is important especially if the executive power in a Member State openly declares the protection of its own nationals and ignores the European citizenship context. For example, in the case of a child abduction to another State the principle is that the authority shall order the return of the child forthwith save for exceptional cases. ${ }^{19}$ But the Polish government treats children who have a Polish parent as Polish children (ignoring the parent of other nationality) and does not hide the wish that they stay in Poland. A law on the central authority in family matters ${ }^{20}$ was recently adopted to enable the Ministry of Justice to supervise judicial proceedings in child abduction cases. ${ }^{21}$ It provides, amongst others, for the right of the Ministry to inquire courts about pending cases and for the obligation of the courts to answer immediately. ${ }^{22}$ The purpose of such supervision is clear from the title of a Ministry leaflet'Stop transferring Polish children abroad'. ${ }^{23}$ The influence of the executive on the judiciary can diminish the protection of rights stemming from EU law including the right to equal treatment.

\footnotetext{
${ }^{18}$ It is interesting to note that the CJEU did see in this provision also the reference to Article 2 TEU (CJEU, LM, supra note 1, para. 45) while Article 1(3) mentions only Article 6 TEU.

${ }^{19}$ Art. 12(2), 13 and 20 Convention of 25 October 1980 on the Civil Aspects of International Child Abduction, complemented by Council Regulation (EC) 2201/2003 concerning jurisdiction and the recognition and enforcement of judgments in matrimonial matters and the matters of parental responsibility, repealing Regulation (EC) No 1347/2000, (2003) OJ L338/1.

${ }^{20}$ Ustawa z dnia 26 stycznia 2018 r. o wykonywaniu niektórych czynności organu centralnego w sprawach rodzinnych z zakresu obrotu prawnego na podstawie prawa Unii Europejskiej i umów międzynarodowych, Dz.U. 2018 poz. 416 (law on the central authority in family matters).

${ }^{21}$ Information from the Polish Ministry of Justice website explains that 'Under current law Ministry of Justice has not had possibilities of efficient supervision on such cases. (...) It is time to finish with it. State must protect Polish children', see www.ms.gov.pl/pl/informacje/news,8926, chronimy-prawa-dzieci-w-postepowaniach.html.

${ }^{22}$ Law of 26 January 2018 on the central authority in family matters, supra note 20, Art. 15.

${ }^{23}$ See www.ms.gov.pl/Data/Files/_public/aktual/2018/2_years_eng_ms.pdf.
} 
In $L M$ the CJEU could have stated that the European area of justice is based on a high level of mutual trust in the administration of justice, but at the same time on the responsibility of Member States to ensure independence of the courts. Such an obligation was recently confirmed by the CJEU in the case Associação Sindical dos Juizes Portugueses (ASJP). ${ }^{24}$ In this case the judicial independence was derived mainly from Articles 2, 4(3) and 19 TEU, while Article 47 of the Charter was treated only as a subsidiary source. The $L M$ judgment takes Article 2 TEU as a starting point, ${ }^{25}$ repeats the statements of the ASJP judgment ${ }^{26}$ and confirms the importance of judicial independence in the context of the EAW. ${ }^{27}$ But these general statements do not find expression in the conclusions of the $L M$ case. In the answer given to the Irish court, judicial independence is reduced to the right of an individual to an independent court as a part of a right to a fair trial. ${ }^{28}$ It is a step back in comparison to the ASJP judgment.

Fortunately, a broader perspective on the independence of the judiciary is taken by the CJEU in a subsequent case relating to the rule of law deficiencies in Poland. A judgment in the Commission v. Poland ${ }^{29}$ case confirms the importance of Article 19 (1) TEU as a main source of obligation of maintaining independent courts by Member States. The most important consequence is a broader scope of application. While fundamental rights (including Article 47 of the Charter) are applied only when Member States are implementing Union law, ${ }^{30}$ Article 19(1) TEU 'refers to 'the fields covered by Union law', irrespective of whether the Member States are implementing Union law within the meaning of Article 51(1) of the Charter'. ${ }^{31}$ The CJEU explained explicitly that the national body falls within the fields covered by EU law if it may be called upon to rule, as a court or tribunal, on questions concerning the application or interpretation of EU law. ${ }^{32}$ As almost any court in Member States can nowadays rule on questions of EU law, each Member State is obliged to ensure that its judiciary as a whole must meet the requirements of effective judicial protection. The CJEU underlined the interdependence between the requirement of independence of the courts stemming from Article 19(1) TEU and the right to effective judicial protection ${ }^{33}$ but the Commission v. Poland judgment shows clearly that the former is something more than the fundamental right of an individual.

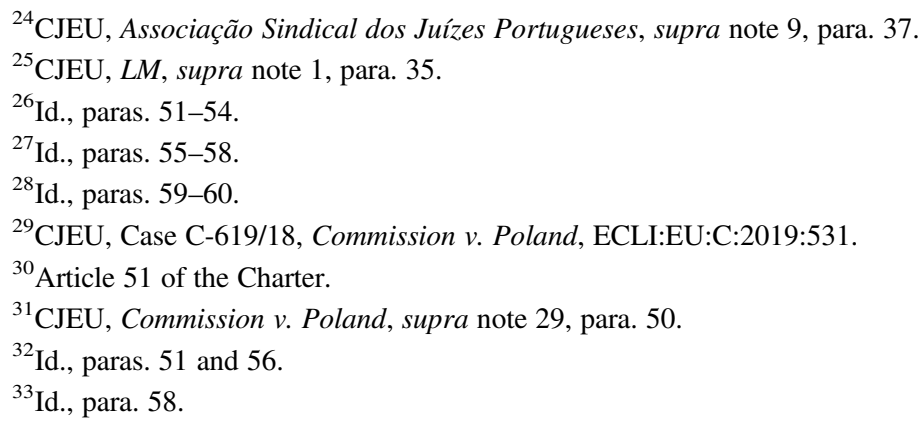




\subsection{Individual Assessment Often Not Feasible in the European Judicial Area}

The Irish question relates only to the EAW, but a broader perspective shall be taken as the restriction of independence of the judiciary has a potential impact on at least 25 acts providing for mutual recognition of judgments. Mutual trust in the administration of justice is the guiding principle of nine framework decisions, two directives related to mutual recognition in criminal matters, and 14 regulations governing mutual recognition in civil matters. In criminal matters there are in chronological order: Directives on European Investigation Order $^{34}$ and European protection order $^{35}$ and framework decisions on: mutual recognition of decisions on supervision measures ${ }^{36}$ decisions rendered in the absence of the person concerned at the trial, ${ }^{37}$ recognition of judgments imposing custodial sentences, ${ }^{38}$ supervision of probation measures and alternative sanctions, ${ }^{39}$ taking account of convictions in the course of new criminal proceedings, ${ }^{40}$ confiscation orders, ${ }^{41}$ mutual recognition to financial penalties, ${ }^{42}$ orders freezing property or evidence, ${ }^{43}$ European arrest warrant. ${ }^{44}$ In

\footnotetext{
${ }^{34}$ Directive (EU) 2014/41 of the European Parliament and of the Council regarding the European Investigation Order in criminal matters (2014) OJ L130/1.

${ }^{35}$ Directive (EU) 2011/99 of the European Parliament and of the Council on the European protection order (2011) OJ L338/2.

${ }^{36}$ Council Framework Decision (JHA) 2009/829 on the application, between Member States of the European Union, of the principle of mutual recognition to decisions on supervision measures as an alternative to provisional detention (2009) OJ L294/20.

${ }^{37}$ Council Framework Decision (JHA) 2009/299 amending Framework Decisions 2002/584/JHA, 2005/214/JHA, 2006/783/JHA, 2008/909/JHA and 2008/947/JHA, thereby enhancing the procedural rights of persons and fostering the application of the principle of mutual recognition to decisions rendered in the absence of the person concerned at the trial (2009) OJ L81/24.

${ }^{38}$ Council Framework Decision (JHA) 2008/909 on the application of the principle of mutual recognition to judgments in criminal matters imposing custodial sentences or measures involving deprivation of liberty for the purpose of their enforcement in the European Union (2008) OJ L327/ 27.

${ }^{39}$ Council Framework Decision (JHA) 2008/947 on the application of the principle of mutual recognition to judgments and probation decisions with a view to the supervision of probation measures and alternative sanctions (2008) OJ L337/102.

${ }^{40}$ Council Framework Decision (JHA) 2008/675 on taking account of convictions in the Member States of the European Union in the course of new criminal proceedings (2008) OJ L220/32.

${ }^{41}$ Council Framework Decision (JHA) 2006/783 on the application of the principle of mutual recognition to confiscation orders (2006) OJ L328/59.

${ }^{42}$ Council Framework Decision (JHA) 2005/214 on the application of the principle of mutual recognition to financial penalties (2005) OJ L76/16.

${ }^{43}$ Council Framework Decision (JHA) 2003/577 on the execution in the European Union of orders freezing property or evidence (2003) OJ L196/45.

${ }^{44}$ Council Framework Decision (JHA) 2002/584 on the European arrest warrant and the surrender procedures between Member States-Statements made by certain Member States on the adoption of the Framework Decision (2002) OJ L190/1.
} 
civil matters there are regulations on: insolvency proceedings, ${ }^{45}$ general civil matters (the so-called Brussels I ${ }^{46}$ ), parental responsibility and divorce (Brussels II bis), ${ }^{47}$ the European Enforcement Order (EEO), ${ }^{48}$ the European Order for Payment (EOP),${ }^{49}$ small claims, ${ }^{50}$ maintenance obligations, ${ }^{51}$ the Brussels I bis Regulation, ${ }^{52}$ the succession, ${ }^{53}$ the European protection order, ${ }^{54}$ European Account Preservation Order, $^{55}$ new regulation on insolvency proceedings, ${ }^{56}$ matrimonial property regimes, ${ }^{57}$ property consequences of registered partnerships. ${ }^{58}$

All acts introducing mutual recognition of judgments relate to judgments of courts/tribunals ${ }^{59}$ or judicial authority. ${ }^{60}$ This notion was considered by the CJEU

\footnotetext{
${ }^{45}$ Council Regulation (EC) 1346/2000 on insolvency proceedings (2000) OJ L160/1.

${ }^{46}$ Council Regulation (EC) 44/2001 on jurisdiction and the recognition and enforcement of judg-
} ments in civil and commercial matters (2001) OJ L12/1.

${ }^{47}$ Council Regulation (EC) 2201/2003 concerning jurisdiction and the recognition and enforcement of judgments in matrimonial matters and the matters of parental responsibility, repealing Regulation (EC) No 1347/2000, (2009) OJ L347/32.

${ }^{48}$ Regulation (EC) $805 / 2004$ of the European Parliament and of the Council creating a European Enforcement Order for uncontested claims (2004) OJ L143/15.

${ }^{49}$ Regulation (EC) 1896/2006 of the European Parliament and of the Council creating a European order for payment procedure (2006) OJ L399/1.

${ }^{50}$ Regulation (EC) 861/2007 of the European Parliament and of the Council establishing a European Small Claims Procedure (2007) OJ L199/1.

${ }^{51}$ Council Regulation (EC) 4/2009 on jurisdiction, applicable law, recognition and enforcement of decisions and cooperation in matters relating to maintenance obligations (2009) OJ L7/1.

${ }^{52}$ Regulation (EU) 1215/2012 of the European Parliament and of the Council on jurisdiction and the recognition and enforcement of judgments in civil and commercial matters (recast) (2012) OJ L351/ 1.

${ }^{53}$ Regulation (EU) 650/2012 of the European Parliament and of the Council on jurisdiction, applicable law, recognition and enforcement of decisions and acceptance and enforcement of authentic instruments in matters of succession and on the creation of a European Certificate of Succession (2012) OJ L201/107.

${ }^{54}$ Regulation (EU) 606/2013 of the European Parliament and of the Council on mutual recognition of protection measures in civil matters (2013) L181/4.

${ }^{55}$ Regulation (EE) 655/2014 of the European Parliament and of the Council establishing a European Account Preservation Order procedure to facilitate cross-border debt recovery in civil and commercial matters (2014) OJ L189/59.

${ }^{56}$ Regulation of the European Parliament and of the Council (EU) 2015/848 on insolvency proceedings (2015) OJ L141/19.

${ }^{57}$ Council Regulation (EU) 2016/1103 implementing enhanced cooperation in the area of jurisdiction, applicable law and the recognition and enforcement of judgments in matters concerning matrimonial property regimes (2016) OJ L183/1.

${ }^{58}$ Council Regulation (EU) No. 2016/1104 implementing enhanced cooperation in the area of jurisdiction, applicable law and the recognition and enforcement of judgments in matters concerning the property consequences of registered partnerships (2016) OJ L183/30.

${ }^{59}$ According to Article 2(a) Brussels I bis: 'judgment' means any judgment given by a court or tribunal of a Member State, whatever the judgment may be called'.

${ }^{60}$ Article 1(1) of Framework Decision 2002/584: 'The European arrest warrant is a judicial decision issued by a Member State (...)'. Article 6 of the same act: ' 1 . The issuing judicial authority shall be 
as an autonomous notion of EU law and interpreted several times in both civil and criminal cases. In the cases Ibrica Zulfikarpašic ${ }^{61}$ and Pula Parking, ${ }^{62}$ the Luxembourg Court stated that, due to mutual trust, EU regulations require 'that judgments the enforcement of which is sought in another Member State [be] delivered in court proceedings offering guarantees of independence and impartiality'. In two cases relating to criminal matters-Kovalkovas ${ }^{63}$ and Poltorak ${ }^{64}$ - the CJEU stated that the term 'judiciary' 'must (...) be distinguished, in accordance with the principle of the separation of powers which characterises the operation of the rule of law, from the executive'. These requirements are difficult to reconcile with the statement of the Venice Commission quoted at the beginning of this chapter that Polish reforms 'enable the legislative and executive powers to interfere in a severe and extensive manner in the administration of justice'.

The most important issue is that a level of integration in the field of judicial cooperation is so high that the judgments issued in one Member State have full effects in other Member States. In civil cases the majority of judgments are automatically recognised and enforceable in the other Member States. In all EU acts on mutual recognition, the review of jurisdiction of another Member State or of the content of the judgment to be recognized is prohibited. In some legal instruments, there are even no legal mechanisms allowing recognition/execution to be refused (for example in the case of maintenance or Article 42 of 2201/2003 regulation relating to child return decisions). The courts in Member States are thus often defenceless to judgments coming from other Member States as there is no proceeding in which they could conduct an individual assessment. An obligation of individual assessment is not suitable to protect other Member States which are obliged to recognise judgments originating from a Member State restricting judicial independence.

\section{Conclusions}

A breach of the obligation to ensure independence of the courts should logically result in suspending the participation of a given Member State in the EU policy area at stake, not (only) because the individual right can be impaired but because the EU should deter a Member State from restricting independence of the judiciary and protect other Member States which are obliged by EU law to recognise and enforce judgments from a Member State breaching the rule of law. It is probable that in the

\footnotetext{
the judicial authority of the issuing Member State which is competent to issue a European arrest warrant by virtue of the law of that State.'

${ }^{61}$ CJEU, Case C-484/15 Ibrica Zulfikarpašić, ECLI:EU:C:2017:199, para. 43.

${ }^{62}$ CJEU, Case C-551/15 Pula Parking, ECLI:EU:C:2017:193, para. 54.

${ }^{63}$ CJEU, Case C-477/16 PPU Kovalkovas, ECLI:EU:C:2016:861, para. 36.

${ }^{64}$ CJEU, Case C-452/16 PPU Poltorak, ECLI:EU:C:2016:784, para. 35.
} 
majority of cases Polish judges will resist the political influence. But the courts in other Member States will never know whether this actually is the case. They would have to make difficult ${ }^{65}$ investigations about the substantial issues of the cases and of the division of powers in Poland. The regular individual assessment can contravene the spirit of mutual trust between the courts and often will be impossible in practice.

Moreover, the non-execution of EAWs can save some individuals but is not capable of resolving the essence of the problem. Firstly, the Aranyosi test can protect one's fundamental rights only partly. This became apparent in the judgment in the $M L^{66}$ case, which limits an obligation to assess detention conditions in the issuing Member State to the first prisons in which it is intended that the person concerned will be held just after the surrender. The CJEU admitted that 'a person who is the subject of a European arrest warrant can, as a general rule, be detained in any prison in the territory of that State. It is generally not possible at the stage of executing a European arrest warrant to identify all the prisons in which such a person will actually be detained ${ }^{9}{ }^{67}$ It means that in reality the individual is not wholly protected against inhuman treatment.

The ideal tool to protect judicial independence would be the one which could solve the source of the problem. And there is a clear difference between prison conditions and the independence of the judiciary. In the Aranyosi judgment, the reason lying at the heart of the breach was a serious, structural incapacity of some Member States to ensure the proper standard of protection in prison. Improvement of the situation is a long, costly and complicated process which the EU could stimulate and support. Differently, in the $L M$ case, the source of the problem has been the will of the governing party. The problem could be very easily and quickly resolved by amending the laws on courts according to the recommendations of the Venice Commission and the European Commission. The only thing that the EU can (and should) do is to set clear limits and the consequences in the case of violations. If the EU had addressed the Hungarian case more promptly, the Polish government would probably not have dared to follow the Hungarian path.

In the $L M$ case the CJEU acted like a human rights court. This circumstance is always very welcome. Perhaps, future cases-especially those based on Article 258 TFEU and on the preliminary reference request from the Polish Supreme Court-will present the Luxembourg court with the opportunity to look at the judicial deficiencies from a broader constitutional perspective and stand up against the destruction of the rule of law in Europe.

\footnotetext{
${ }^{65}$ Rizcallah (2018).

${ }^{66}$ CJEU, Case C-220/18 PPU, ML, ECLI:EU:C:2018:589, para. 87.

${ }^{67}$ Id., para. 81 .
} 


\section{Reference}

Rizcallah C (2018) 'Dear Colleague, Are You Independent Enough?' The fate of the principle of mutual trust in case of systemic deficiencies in a Member State's System of Justice. EU Law Analysis Blog 4 July 2018

Dr. hab. Agnieszka Frąckowiak-Adamska assistant professor, Chair of European and International Law, University of Wrocław, Poland.

Open Access This chapter is licensed under the terms of the Creative Commons Attribution 4.0 International License (http://creativecommons.org/licenses/by/4.0/), which permits use, sharing, adaptation, distribution and reproduction in any medium or format, as long as you give appropriate credit to the original author(s) and the source, provide a link to the Creative Commons license and indicate if changes were made.

The images or other third party material in this chapter are included in the chapter's Creative Commons license, unless indicated otherwise in a credit line to the material. If material is not included in the chapter's Creative Commons license and your intended use is not permitted by statutory regulation or exceeds the permitted use, you will need to obtain permission directly from the copyright holder. 